\title{
PENYULUHAN PALAWIJA DESA RIDAN PERMAI UNTUK KETAHANAN PANGAN SAAT PANDEMI COVID 19
}

\author{
Sularno $^{1}$, Ramdhan Witarsa ${ }^{2}$, Fadhilaturrahmi $^{3}$, Muhammad Syahrul Rizal $^{4}$ \\ ${ }^{2,3,4)}$ Pendidikan Guru Sekolah Dasar, Fakultas Ilmu Pendidikan \\ e-mail: sularno@gmail.com
}

\begin{abstract}
Abstrak
Apabila diperhatikan dari segi fisik, kelompok masyarakat sasaran sangat kekurangan dalam prasarana dan sarana untuk meningkatkan penghasilannya saat pandemi covid 19 . Lingkungan yang akan ditanam belum mempunyai sumber air sendiri, belum memiliki alat olah lahan seperti mesin pemotong rumput, mesin pompa air, hand traktor, dan alat semprot elektrik. Sementara lahan penanaman palawija tersebut sangat luas $(1 / 2$ hektar $)$ dan sangat representatif untuk ditanami palawija. Palawija yang akan ditanam pada lahan ini adalah jagung.
\end{abstract}

Kata kunci: Palawija, Ketahanan Pangan, Covid 19

\section{Abstract}

If observed physically, the target community groups are very lacking in infrastructure and facilities to increase their incomes during the 19th pandemic. The environment to be planted does not yet have its own water source, does not yet have land processing equipment such as lawn mowers, water pumping machines, hand tractors, and electric spray. While the palawija planting area is very large (1/2 hectare) and is very representative for planting palawija. The crops that will be planted on this land are corn.

Keywords: Palawija, Food Security, Covid 19

\section{PENDAHULUAN}

Kelompok masyarakat sasaran pada Penyuluhan Palawija Desa Ridan Permai untuk Ketahanan Pangan Saat Pandemi Covid 19 ini secara spesifik bertempat di RT 003 RW 003 Desa Ridan Permai Kecamatan Bangkinang Kota, Kabupaten Kampar, Provinsi Riau. Kondisi masyarakat sasaran yang akan dilibatkan di RT 003 ini memiliki jumlah Kepala Keluarga (KK) sebanyak $30 \mathrm{KK}$ dengan profil sebagai berikut:

\section{Tabel 1}

\section{Profil Desa Binaan}

\begin{tabular}{|c|c|c|c|c|c|}
\hline \multirow[t]{2}{*}{ Jumlah KK } & \multirow{2}{*}{$\begin{array}{c}\text { Jumlah } \\
\text { Anggota } \\
\text { Keluarga }\end{array}$} & \multicolumn{2}{|c|}{ Jenis Kelamin } & \multicolumn{2}{|c|}{ Usia } \\
\hline & & Laki-laki & Perempuan & Produktif & $\begin{array}{c}\text { Non- } \\
\text { Produktif }\end{array}$ \\
\hline 30 & 120 & 40 & 80 & 66 & 54 \\
\hline \multicolumn{6}{|c|}{ Pekerjaan } \\
\hline Petani & IRT & Pedagang & Guru & PNS & Pensiunan \\
\hline 90 & 10 & 10 & - & - & - \\
\hline
\end{tabular}

Sumber: Buku Besar RT 003 RW 003 Desa Ridan Permai Kecamatan Bangkinang Kota 
Berdasarkan Tabel 1 di atas, sebagian besar masyarakat sasaran bekerja sebagai petani palawija. Hal ini menggambarkan besarnya potensi masyarakat sasaran untuk terlibat dalam Penyuluhan Palawija Desa Ridan Permai untuk Ketahanan Pangan Saat Pandemi Covid 19. Selain itu, pada saat sosialisasi tentang penyuluhan ini, seluruh masyarakat antusias untuk terlibat didalamnya. Berdasarkan survei awal yang telah dilakukan oleh tim pengusul, berikut gambaran kondisi dan potensi wilayah yang didokumentasikan melalui foto-foto:

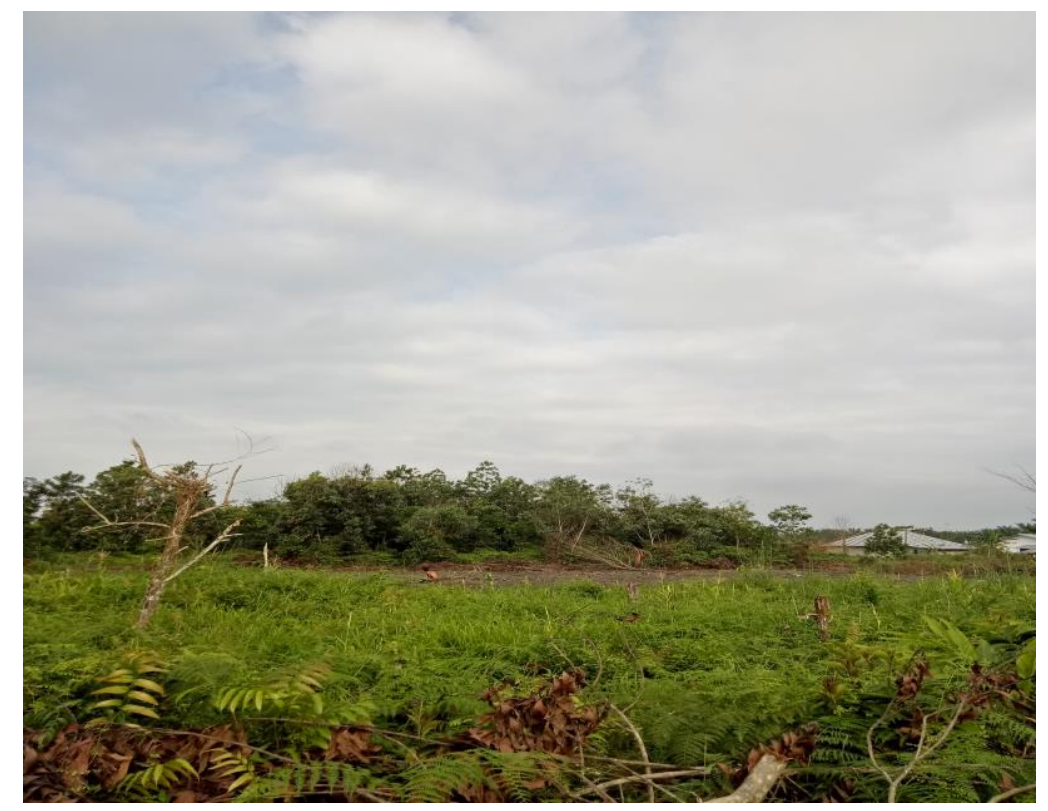

Gambar 1

Lingkungan/Lahan Pertanian yang Sangat Luas dan Representatif

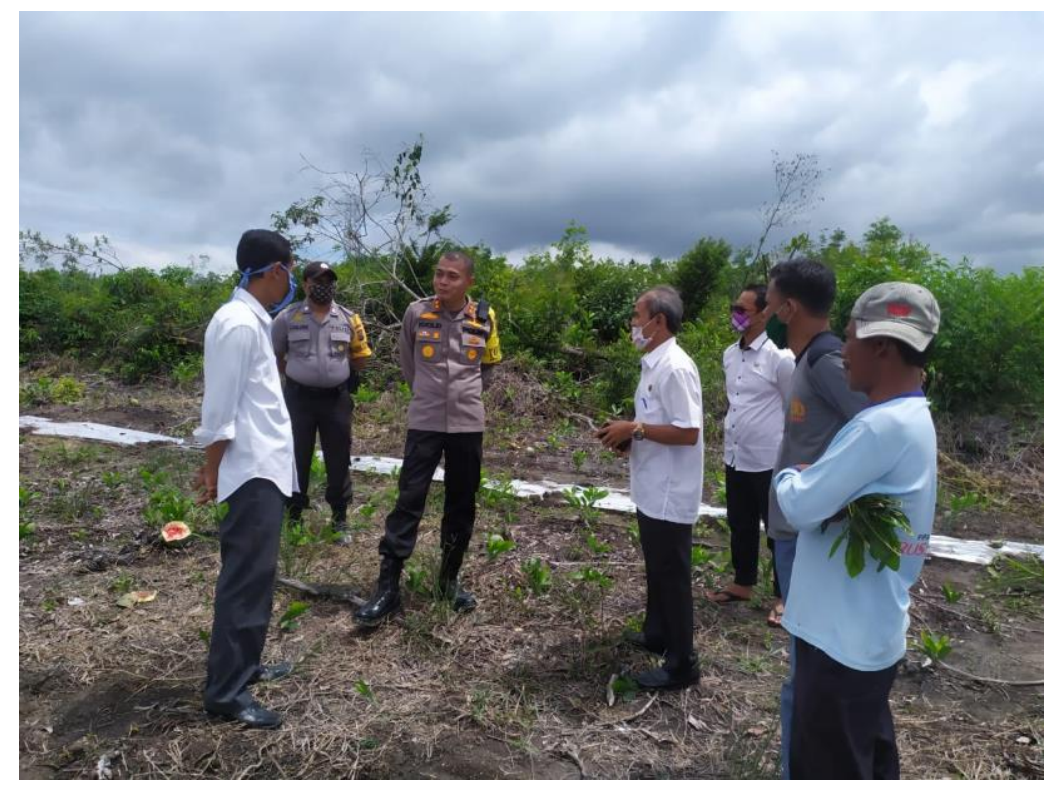

Gambar 2

Posisi Lahan yang Berada di Tengah-tengah Hutan Tidak Menyurutkan Tim untuk Tetap Semangat berkoordinasi dengan Kades dan Polres setempat 


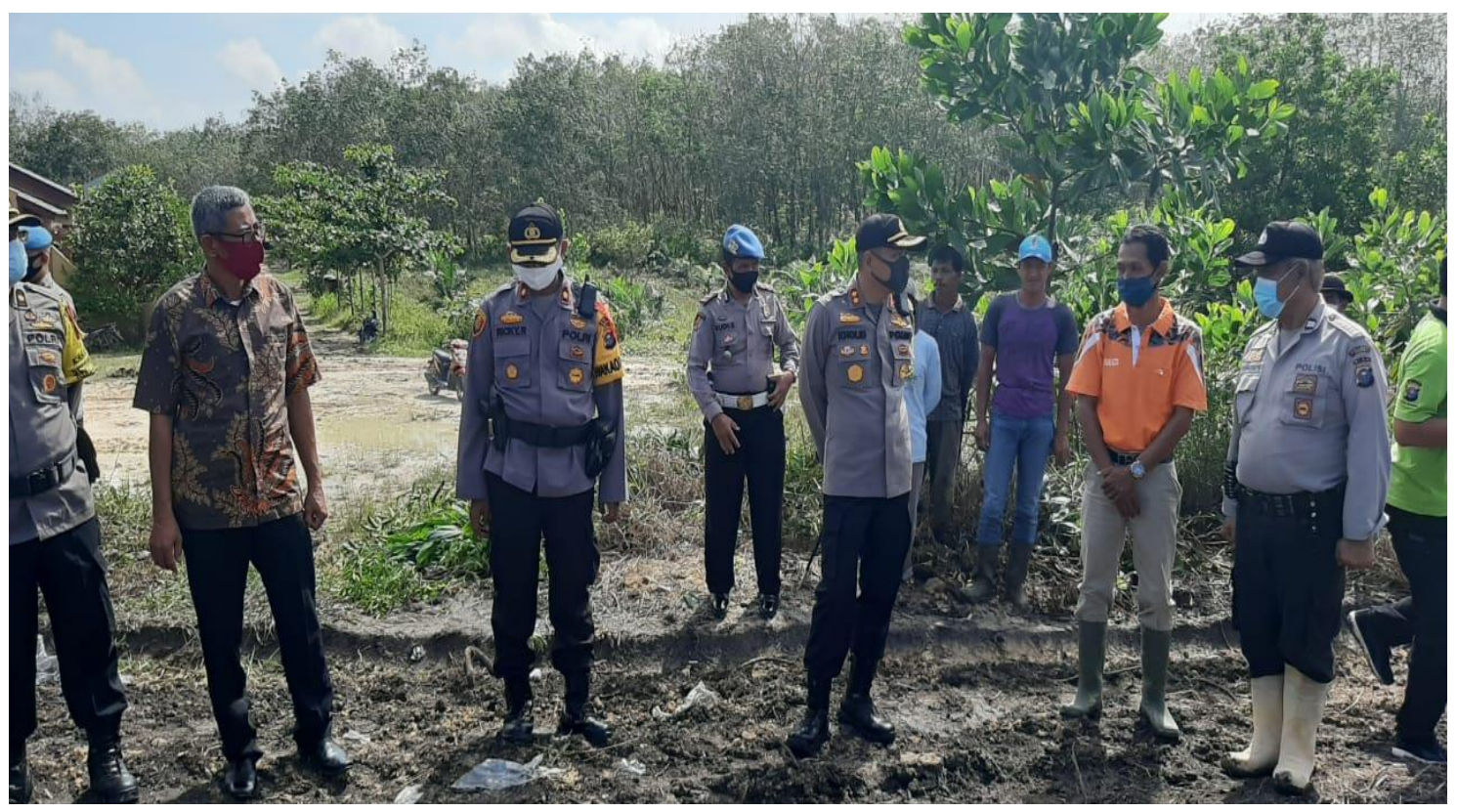

Gambar 3

Lokasi Lahan Palawija (Jagung) yang Tertidur dan Perlu diolah Kembali, berkoordinasi dengan Kades dan Polres setempat

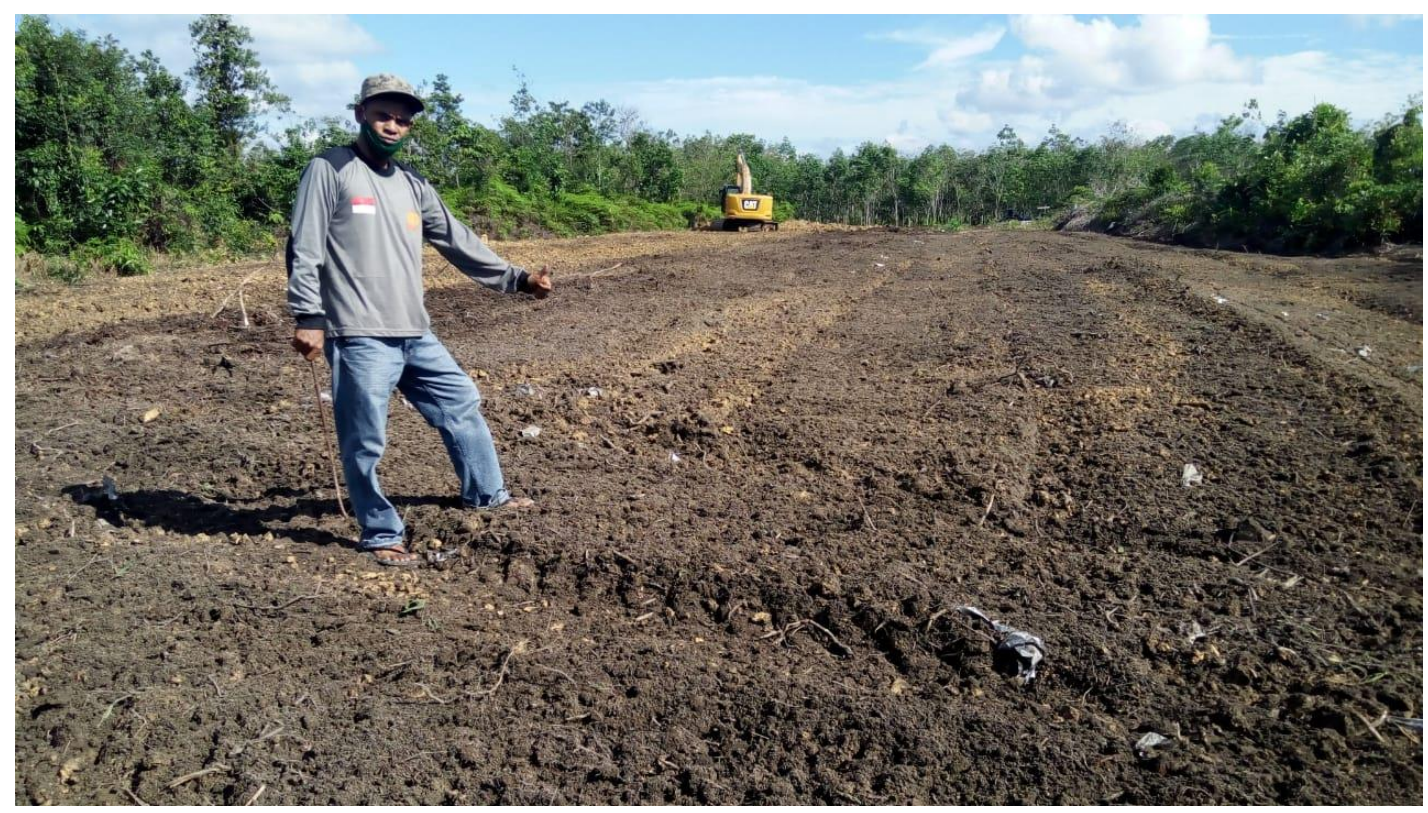

Gambar 4

Lokasi Lahan yang Siap Ditanami Palawija (Jagung) untuk Ketahanan Pangan Saat Pandemi Covid 19

Apabila diperhatikan dari segi fisik, kelompok masyarakat sasaran sangat kekurangan dalam prasarana dan sarana untuk meningkatkan penghasilannya saat pandemi covid 19. Lingkungan yang akan ditanam belum mempunyai sumber air sendiri, belum memiliki alat olah lahan seperti mesin pemotong rumput, mesin pompa air, hand traktor, dan alat semprot elektrik. Sementara lahan penanaman palawija tersebut sangat luas $(1 / 2$ hektar) dan sangat representatif untuk ditanami palawija. Palawija yang akan ditanam pada lahan ini adalah jagung. 
Dari segi sosial, penanaman Palawija jagung ini menjawab tantangan akan terbengkalainya lingkungan lahan yang tidak produktif menjadi lebih produktif dan menjawab kebutuhan saat covid 19. Hal tersebut terbukti dengan banyaknya permintaan masyarakat akan palawija, khususnya jagung.

Dari segi ekonomi, penanaman palawija jagung ini juga memberikan dampak terhadap produktifnya lingkungan lahan dan bertambahnya penghasilan saat covid 19 dan tentu saja relevan dengan semua program kegiatan yang dilakukan oleh kelompok masyarakat sasaran. Berdasarkan hasil survei awal yang telah dilakukan tim pengusul, terdapat beberapa potensi desa yang bisa dikembangkan (palawija dan karet). Namun kami tim pengusul memilih palawija jagung dikarenakan sangat mendesaknya lingkungan lahan yang harus diolah, perlunya masyarakat sasaran diberdayakan, dan menghadapi masa covid 19.

\section{METODE}

Adapun metode pelaksanaan program ini adalah metode penelitian dan pengembangan. Data-data yang dikumpulkan berupa data-data kuantitatif dan kualitatif. Tahapan-tahapan yang dilakukan sebagai berikut: survei awal, membuat draft program, penyuluhan penanaman Palawija jagung melalui sistem Padat Karya dan pendampingan berkelanjutan, uji coba terbatas, pengujian, program penanaman Palawija jagung melalui sistem padat karya dan pendampingan berkelanjutan yang telah teruji.

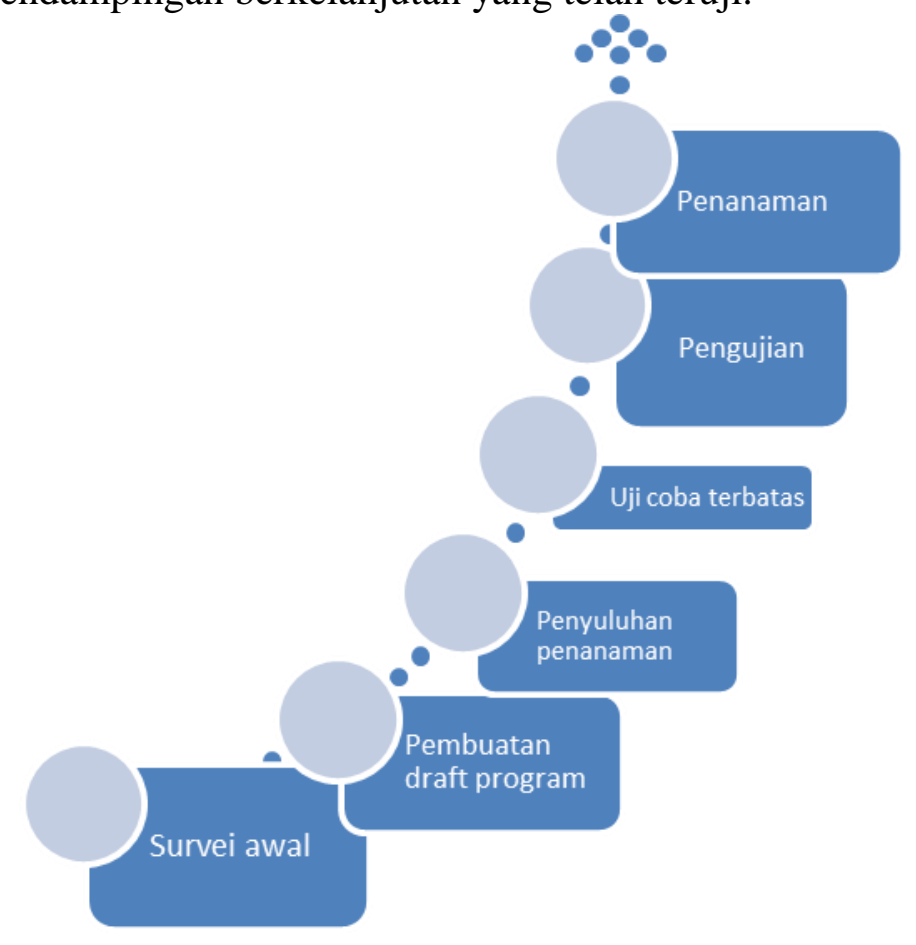

Gambar 3.1

Metode Pelaksanaan

\section{HASIL DAN PEMBAHASAN}

Adanya perubahan perilaku masyarakat (bertambahnya pengetahuan, sikap mental, mindset, dan keterampilan) sesudah dilakukannya Penyuluhan Penanaman Palawija Jagung di Desa Ridan Permai melalui Sistem Padat Karya dan Pendampingan Berkelanjutan. Melalui sistem padat karya dan pendampingan berkelanjutan tersebut, diharapkan 
perubahan-perubahan (pengetahuan, sikap mental, mindset, dan keterampilan) tersebut terus tampak pasca penyuluhan dan pasca covid 19.

Adanya perubahan-perubahan fisik pasca penyuluhan, seperti lingkungan lahan yang lebih produktif, serta peralatan penanaman yang menunjang. Perubahan-perubahan fisik tersebut diukur melalui daftar ceklis.

Adanya MoU-MoU dengan berbagai mitra: a. MoU dengan Penyedia Benih Jagung (untuk menjamin pasokan benih palawija); b. MoU dengan Desa Mitra (sebagai Desa Binaan); c. MoU dengan pengelola Bumdes (sebagai pasar/konsumen tetap) pasca penyuluhan.

Terbentuknya Palawija Center sebagai lembaga lokal di masyarakat sebagai Pembina petani baru yang ingin menjadi pengusaha palawija; Terbentuknya Palawija DRP (Desan Ridan Permai) sebagai pelanjut program yang bergerak dalam bidang distribusi sebagai awal berdirinya Pusat Distribusi Palawija; Program pasca Penyuluhan: Rumah Palawija yang menyediakan berbagai macam jenis palawija yang dibutuhkan pasar dan masyarakat umum dengan harga yang wajar dan menguntungkan petani, khususnya saat covid 19.

\section{SIMPULAN}

Bertambahnya pengetahuan, sikap mental, mindset, dan keterampilan masyarakat sasaran dalam menanam palawija jagung yang baik secara kualitas maupun kuantitas. Lahan-lahan yang lebih produktif dan terstandar, serta peralatan penanaman yang menunjang guna keberlanjutan keanekaragaman hayati sumber pangan, khususnya jagung saat covid 19. Adanya perhatian Penyedia Benih Palawija untuk menjamin pasokan bahan benih palawija, adanya perhatian Pemerintah Kabupaten Kampar dan Provinsi Riau terhadap Desa Ridan Permai sebagai Desa Binaan baik perhatian moril dan fisik; Adanya perhatian Pengelola-pengelola Pasar Tradisonal maupun Modern sebagai konsumen tetap produk Palawija jagung Desa Ridan Permai pasca Penyuluhan. Semakin dikenalnya Palawija Center sebagai lembaga lokal di masyarakat sebagai Pembina petani-petani baru yang ingin menjadi pengusaha Palawija; semakin dikenalnya Palawija DRP sebagai pelanjut program yang bergerak dalam bidang distribusi sebagai awal berdirinya Rumah Palawija.

\section{SARAN}

Saran untuk keberhasilan program yang diharapkan sebagai berikut:

1. Adanya perubahan perilaku masyarakat (bertambahnya pengetahuan, sikap mental, mindset, dan keterampilan) sesudah dilakukannya Penyuluhan Penanaman Palawija Jagung di Desa Ridan Permai melalui Sistem Padat Karya dan Pendampingan Berkelanjutan. Melalui sistem padat karya dan pendampingan berkelanjutan tersebut, 
diharapkan perubahan-perubahan (pengetahuan, sikap mental, mindset, dan keterampilan) tersebut terus tampak pasca penyuluhan dan pasca covid 19.

2. Adanya perubahan-perubahan fisik pasca penyuluhan, seperti lingkungan lahan yang lebih produktif, serta peralatan penanaman yang menunjang. Perubahan-perubahan fisik tersebut diukur melalui daftar ceklis.

3. Adanya MoU-MoU dengan berbagai mitra: a. MoU dengan Penyedia Benih Jagung (untuk menjamin pasokan benih palawija); b. MoU dengan Desa Mitra (sebagai Desa Binaan); c. MoU dengan pengelola Bumdes (sebagai pasar/konsumen tetap) pasca penyuluhan.

4. Terbentuknya Palawija Center sebagai lembaga lokal di masyarakat sebagai Pembina petani baru yang ingin menjadi pengusaha palawija; Terbentuknya Palawija DRP (Desan Ridan Permai) sebagai pelanjut program yang bergerak dalam bidang distribusi sebagai awal berdirinya Pusat Distribusi Palawija; Program pasca Penyuluhan: Rumah Palawija yang menyediakan berbagai macam jenis palawija yang dibutuhkan pasar dan masyarakat umum dengan harga yang wajar dan menguntungkan petani, khususnya saat covid 19.

\section{UCAPAN TERIMA KASIH}

Penulis mengucapkan terima kasih kepada instansi yang telah memberi dukungan financial terhadap pengabdian ini terutama kepada Kepala Desa Ridan.

\section{DAFTAR PUSTAKA}

Peraturan Pemerintah Nomor 12 tahun 2010 tentang Penelitian dan Pengembangan serta Pendidikan dan Pelatihan.

Peraturan Menteri Kehutanan Nomor: P. 29/Menhut-II/2013 tentang Pedoman Pendampingan Kegiatan Pembangunan.

Hasibuan, M.SP. (2010). Manajemen Sumber Daya Manusia. PT. Bumi Aksara: Jakarta.

Suharsimi. (2011). Prosedur Penelitian. Rhineka Cipta: Jakarta.

Wursanto. (2009). Manajemen Kepegawaian 1. Penerbit Kanisius: Jogyakarta.

Armstrong, M. (2006). A Handbook of Human Resource Management Practice (10th Edition). London: Kogan Page. 